\title{
Gerakan Buru Membaca sebagai Media Pembelajaran Masyarakat di Kabupaten Buru
}

Abdi Wael, Idrus Hentihu, Rosita Umanailo, Hamiru Hamiru, Mansyur Nawawi, Sukainap Pulhehe, Mirja Ohoibor, Riki Bugis, Edi Said Ningkeula SP, Muhammad Bula, Lutfi Rumkel, Iskandar Hamid, Irma Magfirah, Said Abdurahman Assagaf, Siami Prafitriyani, Abdul Latif Wabula, Belinda Sam, Wa Malmia, Syaiful Rachman, Salmah Yusuf, M Yusran Zakaria

Universitas Iqra Buru

chairulbasrun@gmail.com

\begin{abstract}
Abstrak
Tujuan penelitian ini mendapatkan gambaran primer tentang media pembelajaran masyarakat yang terbangun melalui gerakan buru membaca di Kecamatan Namlea. Pendekatan yang dipergunakan dalam penelitian ini menggunakan pendekatan kualitatif dan Jumlah informan yang akan diwawancarai sebanyak 30 orang yang diambil secara purposive dengan pertimbangan responden dianggap sebagai pihak-pihak yang terkait untuk mencapai tujuan penelitian. Penelitian dilakukan di Kecamatan Namlea Kabupaten Buru dengan sampel wilayah adalah Desa Namlea, Desa Jamilu dan Desa Lala. Penelitian ini menggunakan teknik pengumpulan data atau teknik yang menggunakan observasi, wawancara mendalam untuk mendapatkan data kondisi kondisi sosial budaya masyarakat, terkait pelaksanaan gerakan buruo membaca. Teknik analisis yang digunakan dalam penelitian ini adalah analisis data kualitatif mengikuti konsep yang diberikan Miles and Huberman dan Spradley.
\end{abstract}

Keyword: gerakan, masyarakat, buru, membaca, pembelajaran

Kecamatan Namlea merupakan Ibukota Kabupaten Buru terdiri dari 11 desa dan 9 dusun. Luas wilayah Kecamatan Namlea 226,55 $\mathrm{Km}^{2}$ serta yang memiliki jumlah penduduk terbanyak di Kabupaten Buru. Penduduk Kecamatan Namlea menurut data Biro Pusat Statistik tahun 2017 adalah 34.326 jiwa. Jumlah ini bertambah terus setiap tahun dengan laju pertumbuhan penduduk 6,26 persen (Data BPS, 2017). Dengan pertambahan penduduk ini, secara otomatis mengakibatkan semakin tingginya heterogenitas penduduk yang berada di Kecamatan Namlea. Peningkatan kepadatan penduduk yang sedemikian cepat dapat mengakibatkan heterogenitas menjadi sebuah ancaman yang mengganggu proses kehidupan bermasyarakat.

Memahami karakter masyarakat Kabupaten Buru sebagai Karakter masyarakat yang heterogen, konsekuensi sebagai daerah baru, yang memiliki berbagai potensi sumberdaya alam dan karakterisktik masyarakat yang semakin majemuk maka Pemerintah Daerah melalui Dinas Pendidikan bersama-sama dengan Universitas Iqra Buru serta Kementerian Pendidikan mengkonstruksi sebuah program bertujuan untuk menangkal berbagai pengaruh buruk atau dampak negatif dari perkembangan komunikasi bagi kehidupan bermasyarakat di Kabupaten Buru, serta dalam meningkatkan masyarakat yang cerdas dan kaya akan ilmu pengetahuan sehingga dalam kegiatan tersebut dilakukan model membaca 1 buku mengerti 10 buku. Gerakan buru membaca kemudian menjadi paradigma baru untuk pendidikan dan pembelajaran masyarakat di Kabupaten Buru.

Mengoptimalkan waktu untuk membaca bukanlah hal baru maupun trend popular namun telah ada sebelumnya dengan pembelajaran pada lembaga formal mauun informal, namun seiring perkembangan teknologi yang terjadi malah sebaliknya, banyak diantara masyarakat yang kurang bijak dalam memanfaatkan waktu luang serta kesempatan untuk membaca sehingga berdampak pada pola pikir dan pola tindak dalam kehidupan sehari-hari. 
Agustin (2017) dalam penelitiannya tentang gerakan literasi sekolah untuk meningkatkan budaya baca di SMA Negeri 1 Geger mengemukakan penerapan Gerakan Literasi Sekolah (GLS) sudah mulai menunjukkan gaungnya. Beberapa pihak yang merupakan komponen penting dari gerakan literasi ini, secara pelan tetapi pasti mulai menunjukkan kepeduliannya. Pelaksanaan GLS di lapangan, dilakukan pada pagi hari sebelum jam pertama atau sebelum memulai kegiatan belajar mengajar. Sementara itu, Wibowo (2013) dalam penelitiannya tentang gerakan taman baca "perpustakaan dusun" dari mahasiswa untuk desa, menjelaskan Buku dan membaca adalah dua sisi mata uang yang saling berkaitan. Meskipun saat ini sudah beragam media dalam memfasilitasi kegiatan membaca akan tetapi tetap bukulah yang menjadi pilihan utama. Membiasakan membaca butuh proses dan waktu untuk bisa membumikannya dalam kehidupan sehari-hari. Faktor lingkungan dan ketidaktersediaan fasilitas sangat mempengaruhi hal tersebut.

Faktor yang mendorong atas bangkitnya minat baca ialah ketertarikan, kegemaran, dan hobi membaca, dan pendorong tumbuhnya kebiasaan membaca adalah kemauan dan kemampuan membaca. Berseminya budaya baca adalah kebiasan membaca, sedangkan kebiasan membaca terpelihara dengan tersedianya bahan bacaan yang baik, menarik, memadai, baik jenis, jumlah, maupun mutunya. Inilah sebuah formula yang secara ringkas untuk mengembangkan minat dan budaya baca (Syahrir, 2016). Dari rumusan konsepsi tersebut tersirat tentang perlunya minat baca itu dibangkitkan sejak usia dini (anak-anak). Hal itu dimulai dengan perkenalan dengan bentuk-bentuk huruf dan angka pada masa pendidikan pra sekolah hingga mantapnya penguasaan membaca- menulis-berhitung pada awal pendidikan di sekolah dasar.

Menurut beberapa hasil penelitian dalam kutipan Billi Antoro menyebutkan bahwa kegiatan membaca dapat menjaga kesehatan otak, meningkatkan kecerdasan logika dan linguistik sehingga anak yang rajin membaca akan cenderung lebih baik dalam memahami berbagai persoalan, baik yang berkaitan dengan mata pelajaran di sekolah maupun dengan kehidupannya sehari-hari (Antoro, 2017). Tingkat literasi masyarakat Indonesia beberapa tahun belakangan ini telah semakin meningkat. Namun, beberapa hasil survei international masih mendorong gerakan literasi. Laporan PIRLS 2011 menyatakan bahwa minat baca peserta didik kelas 4 Sekolah Dasar di Indonesia masih menduduki peringkat ke-45 dari 48 negara peserta, dengan perolehan skor 428 dari skor rata-rata 500 (Thompson et al., 2012).

Jadi, tanpa tersedianya bahan bacaan, kebutuhan tersebut tidak dapat dipenuhi atau dipuaskan, dan mungkin saja kebiasan membaca tersebut tentu akan menyusut. Kebiasaan membaca tersebut mudah dipengaruhi oleh kebiasaan menonton melalui media elektronik yang sajiannya bersifat audio visual. Sehubungan dengan minat, kebiasaan, dan budaya baca tersebut, paling tidak ada tiga tahapan yang harus dilalui, yaitu: pertama, dimulai dengan adanya kegemaran karena tertarik bahwa buku- buku tersebut dikemas dengan menarik, baik disain, gambar, bentuk dan ukurannya. Di dalam bacaan tertentu terdapat sesuatu yang menyenangkan diri pembaca. Kedua, setelah kegemaran tersebut dipenuhi dengan ketersedian bahan dan sumber bacaan yang sesuai dengan selera, ialah terwujudnya kebiasaan membaca. Kebiasaan itu dapat terwujud manakala sering dilakukan, baik atas bimbingan orang tua, guru atau lingkungan di sekitarnya yang kondusif, maupun atas keinginan anak tersebut. Ketiga, jika kebiasan membaca itu terus dipelihara, tanpa "gangguan". Penelitian ini dilakukan berdasarkan preferensi pelaksanaan program gerakan buru membaca di Kecamatan Namlea sebagai upaya rekayasa sosial dalam aktualisasi pola pendidikan.

Faktor yang mendorong atas bangkitnya minat baca ialah ketertarikan, kegemaran, dan hobi membaca, dan pendorong tumbuhnya kebiasaan membaca adalah kemauan dan kemampuan membaca. Berseminya budaya baca adalah kebiasan membaca, sedangkan kebiasan membaca terpelihara dengan tersedianya bahan bacaan yang baik, menarik, memadai, baik jenis, jumlah, maupun mutunya. Inilah sebuah formula yang secara ringkas untuk mengembangkan minat dan budaya baca (Syahrir, 2016). Dari rumusan konsepsi tersebut tersirat tentang perlunya minat baca itu dibangkitkan sejak usia dini (anak-anak). Hal itu dimulai dengan perkenalan dengan bentuk-bentuk 
huruf dan angka pada masa pendidikan pra sekolah hingga mantapnya penguasaan membaca- menulis-berhitung pada awal pendidikan di sekolah dasar.

Menurut beberapa hasil penelitian dalam kutipan Billi Antoro menyebutkan bahwa kegiatan membaca dapat menjaga kesehatan otak, meningkatkan kecerdasan logika dan linguistik sehingga anak yang rajin membaca akan cenderung lebih baik dalam memahami berbagai persoalan, baik yang berkaitan dengan mata pelajaran di sekolah maupun dengan kehidupannya sehari-hari (Antoro, 2017). Tingkat literasi masyarakat Indonesia beberapa tahun belakangan ini telah semakin meningkat. Namun, beberapa hasil survei international masih mendorong gerakan literasi. Laporan PIRLS 2011 menyatakan bahwa minat baca peserta didik kelas 4 Sekolah Dasar di Indonesia masih menduduki peringkat ke-45 dari 48 negara peserta, dengan perolehan skor 428 dari skor rata-rata 500 (Thompson et al., 2012).

Jadi, tanpa tersedianya bahan bacaan, kebutuhan tersebut tidak dapat dipenuhi atau dipuaskan, dan mungkin saja kebiasan membaca tersebut tentu akan menyusut. Kebiasaan membaca tersebut mudah dipengaruhi oleh kebiasaan menonton melalui media elektronik yang

sajiannya bersifat audio visual. Sehubungan dengan minat, kebiasaan, dan budaya baca tersebut, paling tidak ada tiga tahapan yang harus dilalui, yaitu: pertama, dimulai dengan adanya kegemaran karena tertarik bahwa bukubuku tersebut dikemas dengan menarik, baik disain, gambar, bentuk dan ukurannya. Di dalam bacaan tertentu terdapat sesuatu yang menyenangkan diri pembaca. Kedua, setelah kegemaran tersebut dipenuhi dengan ketersedian bahan dan sumber bacaan yang sesuai dengan selera, ialah terwujudnya kebiasaan membaca. Kebiasaan itu dapat terwujud manakala sering dilakukan, baik atas bimbingan orang tua, guru atau lingkungan di sekitarnya yang kondusif, maupun atas keinginan anak tersebut. Ketiga, jika kebiasan membaca itu terus dipelihara, tanpa "gangguan"

media elektronik, yang bersifat entertainment, dan tanpa membutuhkan keaktifan fungsi mental. Oleh karena seseorang pembaca terlibat secara konstruktif dalam menyerap dan memahami bacaan, maka tahap selanjutnya ialah bahwa membaca menjadi kebutuhan yang harus dipenuhi (Syahrir, 2016).

Setelah tahap-tahap tersebut dapat dilalui dengan baik, maka pada diri seseorang tersebut mulai terbentuk adanya suatu budaya baca. Sebuah budaya memberikan corak warna, yang tergambarkan dalam pola pikir, sikap, perilaku, seperti bagaimana cara pandang dan respon dalam kehidupan sehari-hari yang apa adanya, alamiah, dan kultural.

Ketika diamati dengan cermat ada beberapa faktor yang mampu mendorong bangkitnya minat baca masyarakat. Faktor-faktor tersebut adalah: (1) rasa ingin tahu yang tinggi atas fakta, teori, prinsip, pengetahuan, dan informasi, (2) keadaan lingkungan fisik yang memadai, dalam arti tersedianya bahan bacaan yang menarik, berkualitas, dan beragam, (3) keadaan lingkungan sosial yang lebih kondusif, maksudnya adanya iklim yang selalu dimanfaatkan dalam waktu tertentu untuk membaca, (4) rasa haus informasi, rasa ingin tahu, terutama yang aktual, (5) berprinsip hidup bahwa membaca merupakan kebutuhan rokhani. Faktor-faktor tersebut dapat terpelihara melalui sikap-sikap, bahwa dalam diri tertanam komitmen membaca memperoleh keuntungan ilmu pengetahuan, wawasan /pengalaman dan kearifan. Terwujudnya kondisi yang mendukung terpeliharanya minat baca, adanya tantangan dan motivasi untuk membaca, serta tersedianya waktu untuk membaca, baik di rumah, perpustakaan ataupun ditempat lain. Dalam masyarakat kita yang telah berkembang budaya tutur, oral atau lisan, maka masih membutuhkan tekad dan semangat untuk mengubahnyamenjadi budaya baca-tulis. Namun yang paling penting adalah bahwa hal itu seharusnya dimulai dengan tindakan nyata, tidak terbatas wacana atau discourses (Syahrir, 2016). 


\section{Referensi}

Agustin, Sri. 2017. Gerakan Literasi Sekolah Untuk Meningkatkan Budaya Baca di SMA Negeri 1 Geger. Linguista, 1 (2).

Antoro, B. 2017. Gerakan Literasi Sekolah dari Pucuk Hingga Akar (Sebuah Refleksi). Banjarmasin: Direktorat Jenderal Pendidikan Dasar dan Menengah Kementerian Pendidikan dan Kebudayaan.

BPS. 2017. Namlea Subdistrict In Figures. Publication Number : 81040.1706. BPS Statistics of Buru Regency.

Hamid, I. (2010). Identifikasi gulma pada areal pertanaman cengkeh Eugenia aromatica) di Desa Nalbessy Kecamatan Leksula Kabupaten Buru Selatan. Agrikan: Jurnal Agribisnis Perikanan, 3(1), 62-71.

Hentihu, Idrus (2007) Analisisi Pemasaran Tanaman Nilam (Pogostemon cablin Benth)( Studi Kasus Desa Pamotan Kecamatan Dampit Kabupaten Malang ). Other thesis, University of Muhammadiyah Malang. diakses tanggal 15 Agustus 2018.

Indra, Delfi. 2014. Pelaksanaan Manajemen Program Gerakan Masyarakat Magrib Mengaji Di Provinsi Sumatera Barat. Jurnal alFikrah, 2 (2); 101-113.

Magfirah, I. (2017). Efektivitas Model Pembelajaran Discovery dengan Setting Kooperatif Ditinjau dari Kemampuan Analogi dan Generalisasi Matematis Siswa Kelas VII MTs Al-Fakhriyah Makassar (Doctoral dissertation, Universitas Negeri Makassar).

Magfirah, I., Rahman, U., \& Sulasteri, S. (2015). Pengaruh Konsep Diri Dan Kebiasaan Belajar Terhadap Hasil Belajar Matematika Siswa Kelas Viii Smp Negeri 6 Bontomatene Kepulauan Selayar. MaPan: Jurnal Matematika dan Pembelajaran, 3(1), 103116.

Nawawi, M., \& Agus Sudaryanto, S. H. (2009). Perkawinan adat sasi dan akibatnya terhadap hukum kekerabatan adat di Desa Debowae Kecamatan Waeapo Kabupaten Buru (Doctoral dissertation, Universitas Gadjah Mada).

Ningkeula, E. S. (2015). Analisis karakteristik metereologi dan morfologis DAS Wai Samal Kecamatan Seram Utara Timur Kobi Kabupaten Maluku Tengah. Agrikan: Jurnal Agribisnis Perikanan, 8(2), 81-91.

Ningkeula, E. S. (2016). Analisis karakteristik morfometri dan hidrologi sebagai ciri karakteristik biogeofisik DAS Wai Samal Kecamatan Seram Utara Timur Kobi Kabupaten Maluku Tengah. Agrikan: Jurnal Agribisnis Perikanan, 9(2), 76-86.

Pulhehe, S. (2001). Tinjauan PP Nomor 10 Tahun 1983 Menurut Hukum Islam (Perkawinan-Perceraian) (Doctoral dissertation, Universitas Airlangga).

Rahman, M. Syaiful. 2014. Islam Dan Pluralisme. Fikrah, 2 (1); 401-418.

Sapendi. 2012. Pendidikan Pluralisme Agama: Membangun Hubungan Sosial Lintas Agama Di Sekolah. Jurnal Khatulistiwa: Journal Of Islamic Studies, 2 (2); 154-172.

Syahrir, M. 2016. Persepsi masyarakat Kelurahan Baru Kota Makassar terhadap "Gerakan Makassar Gemar Membaca". Khizanah Al-Hikmah Jurnal Ilmu Perpustakaan, Informasi, dan Kearsipan , 4(2), 179-199.

Thompson, S., Provasnik, S., Kastberg, D., Ferraro, D., Lemanski, N., Roey, S., \& Jenkins, F. 2012. Highlights from PIRLS 2011: Reading Achievement of US Fourth- Grade Students in an International Context. United State: National Center for Education Statistics.

Umanailo, M Chairul Basrun. (2019). Strategi Bertahan Hidup Petani Padi Gogo Di Pulau Buru Survival Strategies Of The Upland Rice Farmers In Buru Island. Jurnal Ekonomi Pertanian dan Agribisnis, 3 (1);50-58.

Umanailo, M Chairul Basrun. 2017. “Kajian dan Analisis Sosiologi.” OSF. December 11. doi:10.17605/OSF.IO/PV24F.

Umanailo, M Chairul Basrun. 2017. "Marginalisasi Buruh Tani Akibat Alih Fungsi Lahan." OSF. December 11. doi:10.17605/OSF.IO/9CZK2.

Umanailo, M Chairul Basrun. 2017. “Masyarakat Buru Dalam Perspektif Kontemporer.” OSF. December 10. doi:10.17605/OSF.IO/KZGX3.

Umanailo, M Chairul Basrun. 2017. “Mengurai Kemiskinan Di Kabupaten Buru.” OSF. November 4. doi:10.17605/OSF.1O/8WDXE.

Umanailo, M Chairul Basrun. 2018. "Ilmu Sosial Budaya Dasar." OSF. March 17. doi:10.17605/OSF.IO/4HPWC.

Umanailo, Rosita (2009) Studi Tentang Struktur Dan Komposisi Hutan Pantai Sendang Biru Malang Selatan. Other Thesis, University Of Muhammadiyah Malang. http://eprints.umm.ac.id/11153/ diakses tanggal 15 Agustus 2018.

Umanailo, Rosita (2013) Implementasi Kebijakan Perum Perhutani Dalam Pengelolaan Sumberdaya Hutan Bersama Masyarakat Sekitar Hutan (Studi Di Wilayah Perum Perhutani Kph Malang). Masters thesis, University of Muhammadiyah Malang. http://eprints.umm.ac.id/30546/ diakses tanggal 15 Agustus 2018.

Zakaria, M. Y. (2017). Karakteristik Penyelesaian Masalah Matematika ditinjau dari Kecenderungan Kepribadian Pada Siswa kelas X SMA Negeri 16 Makassar (Doctoral dissertation, Pascasarjana). 